\title{
Ефективність та безпека комбінованої терапії небівололом та розувастатином у пацієнтів із супутньою артеріальною гіпертензією та гіперліпідемією*
}

\author{
А.Р. Хиць \\ Редакція журналу «Український медичний часопис»
}

Анотація. У статті наведено огляд результатів дослідження, в якому оцінювали ефективність та безпеку комбінованої терапії небівололом та розувастатином у пацієнтів із супутньою артеріальною гіпертензією та гіперліпідемією.

Ключові слова: артеріальна гіпертензія, гіперліпідемія, небіволол, розувастатин.

\section{Вступ}

Артеріальна гіпертензія (АГ) разом із гіперліпідемією $\epsilon$ відомими модифікуючими факторами ризику розвитку серцевосудинних захворювань (СС3), які часто можуть «співіснувати» в одного пацієнта [1]. На сьогодні відомо, що наявність АГ та гіперліпідемії негативно позначається на перебігу СС3, тоді як комплексне лікування обох хвороб значно знижує ризик розвитку серцево-судинних ускладнень [2, 3].

Сучасні дані свідчать, що зниження рівня холестерину ліпопротеїдів низької щільності (ХС ЛПНЩ) за допомогою статинотерапії $\epsilon$ ефективною стратегією як для первинної, так і вторинної профілактики серцево-судинних ускладнень [4]. Відповідно до сучасних рекомендацій призначення блокаторів $\beta$-адренорецепторів не пропонується як терапія першої лінії при неускладненій АГ через їх нижчу ефективність порівняно з іншими класами антигіпертензивних препаратів [5, 6]. Однак сьогодні вважається, що здатність блокаторів $\beta$-адренорецепторів впливати на метаболізм ліпідів та глюкози компенсує їх недостатню активність щодо зниження рівня артеріального тиску (АТ) [7]. Крім того, блокатори $\beta$-адренорецепторів, незважаючи на всі наявні розбіжності, продовжують займати важливе місце у лікуванні пацієнтів з такими ССЗ, як АГ, ішемічна хвороба серця, серцева недостатність та фібриляція передсердь [8]. Відповідно, комбінована терапія блокаторами $\beta$-адренорецепторів разом зі статинами може бути корисною при лікуванні пацієнтів із серцево-судинною патологією та гіперліпідемією.

Небіволол - блокатор $\beta$-адренорецепторів III покоління, на відміну від інших препаратів цієї групи, має кращий метаболічний профіль, завдяки його вазодилататорним властивостям, які забезпечуються здатністю препарату модулювати вивільнення ендотеліоцитами оксиду азоту [9]. Однак до сьогодні жодне з існуючих досліджень не оцінювало ефективність комбінованої терапії небівололом разом зі статинами порівняно з монотерапією статинами або небівололом щодо їх здатності впливати на рівень АТ та ліпідів.

Мета дослідження - оцінити ефективність та безпеку комбінованої терапії небівололом та розувастатином щодо впливу на показники АТ та ліпідів у пацієнтів із супутньою АГ та гіперліпідемією.

\section{Об'єкт і методи дослідження}

Проведено рандомізоване подвійне сліпе дослідження, в якому брали участь дорослі пацієнти із супутньою АГ та гіперлі-

*3а матеріалами: Rhee M.-Y., Kim Ch.H., Ahn Y. et al. (2020) Efficacy and Safety of Nebivolol and Rosuvastatin Combination Treatment in Patients with Concomitant Hypertension and Hyperlipidemia. Drug Des. Devel. Ther., 14: 5005-5017. doi: 10.2147/DDDT.S280055. підемією, яких після 4- або 6-тижневої модифікації способу життя рандомізовано на три групи у співвідношенні 1:1:1:

- NEBI/RSV (комбінована терапія небівололом у дозі 5 мг та розувастатином у дозі 20 мг 1 раз на добу);

- RSV (монотерапія розувостатином у дозі 20 мг 1 раз на добу);

- NEBI (монотерапія небівололом у дозі 5 мг 1 раз на добу).

Лікування тривало протягом 8 тиж, препарати приймали 1 раз на добу щоранку.

Критерії включення у дослідження визначені так: дорослі пацієнти віком 20-79 років із супутньою АГ (систолічний АТ 140-179 мм рт. ст. та діастолічний АТ $\leq 109$ мм рт. ст. або лікування антигіпертензивними препаратами на даний момент) та гіперліпідемія (визначали відповідно до критеріїв Adult Treatment Panel III National Cholesterol Education Program (NCEP ATP III) [10].

Критерії виключення 3 дослідження: рівень ХС ЛПНЩ $>250$ мг/дл та/або рівень тригліцеридів $\geq 400$ мг/дл; зміни рівня систолічного АТ в положенні сидячи (Sitting Systolic Blood Pressure - sitSBP) $\geq 20$ мм рт. ст. або зміни рівня діастолічного AT в положенні сидячи (sitDBP) $\geq 10$ мм рт. ст., або наявність таких супутніх станів, як симптоматична ортостатична гіпотензія, вторинна гіпертензія, тяжка серцева недостатність (III-IV клас за класифікацією NYHA); клінічно значуща клапанна хвороба серця, інфаркт міокарда та нестабільна стенокардія; брадикардія (<60 уд./хв), атріовентрикулярна блокада II-III ступеня; неконтрольовані аутоімунні захворювання; бронхоспазм або бронхіальна астма, неконтрольований цукровий діабет та ін.

У якості первинної оцінки ефективності дослідження обрані: (1) зміна sitSBP після 8-тижневого періоду лікування порівняно з вихідним рівнем, яку оцінювали між групами NEBI/RSV та RSV, i (2) зміна рівня XС ЛПНЩ після 8-тижневого періоду лікування порівняно з вихідним рівнем, яку оцінювали між групами NEBI/ RSV ta NEBI.

\section{Результати}

Різниця у зниженні АТ від вихідного рівня після 8-тижневого періоду лікування була більшою у групі NEBI/RSV порівняно з групою RVS, але не відрізнялася від такої у групі NEBI. Різниця у зменшенні sitSBP від вихідного рівня після 8-тижневого періоду лікування була значно більшою у групі NEBI/RSV порівняно 3 групою RSV (середня різниця (CP)= -5,89 мм рт. ст.; 95\% довірчий інтервал (ДІ) -9,88...-1,90 мм рт. ст.), але не відрізнялася від такої у групі NEBI (CP=1,85; 95\% ДI-2,23-5,93 мм рт. Ст.). Подібним чином відзначали також різницю в зниженні показника sitDBP, яка була значно більшою у групі NEBI/RSV порівняно з групою $\mathrm{RSV}$ (CP=-5,99 мм рт. ст.; 95\% ДІ -8,13...-3,84 мм рт. ст.), але не відрізнялася від такої у групі NEBI (CP=0,45 мм рт. ст.; 95\% ДІ -1,722,62 мм рт. ст.) (рисунок, a). 
Рисунок $\quad a$ - рівень контролю, 6 - відповідь АТ, в - показник рівня ХС лПНЩ після 8-тижневої терапії із застосуванням 5 мг небівололу та 20 мг розувастатину (NEBI/RSV), 20 мг розувастатину (RSV) або 5 мг небівололу (NEBI)

$a$

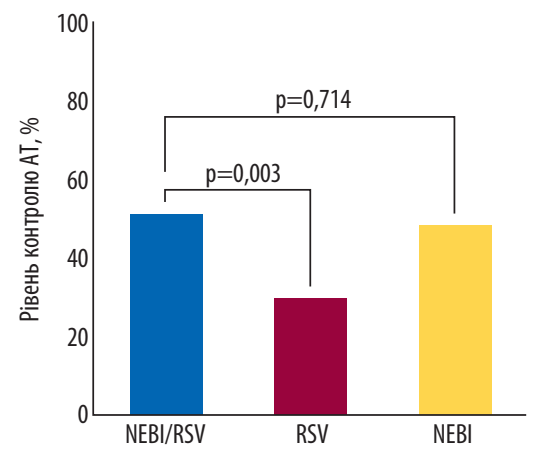

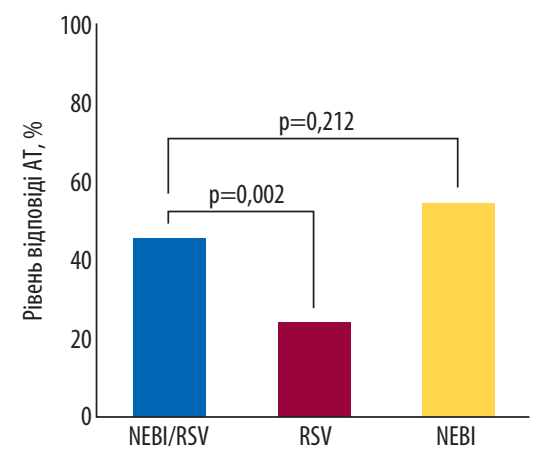

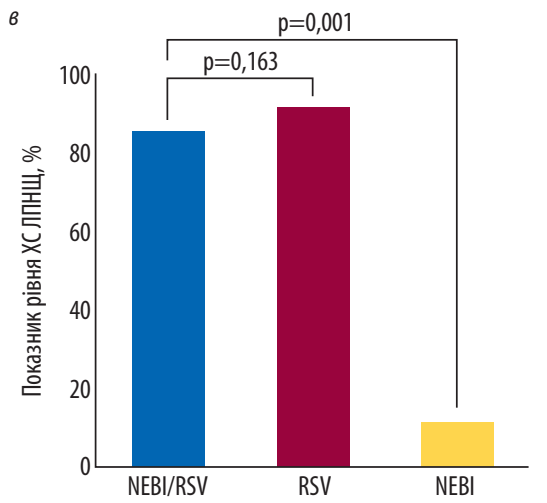

Рівень контролю АТ становив 51,09\% у групі NEBI/RSV, $29,67 \%$ - у групі RSV та 48,39\% - у групі NEBI (рисунок, б).

Зниження рівня ХС ЛПНЩ від вихідного показника після 8-тижневого періоду лікування було більшим у групі NEBI/RSV порівняно з групою NEBI (CP=-47,76\%; $95 \%$ ДI $-52,69 . . .-42,84 \%)$, але не відрізнялося від такого у групі RSV (CP=1,50\%; 95\% ДI $-3,05-6,06 \%)$.

Показник ХС ЛПНЩ досягнув 85,87\% у групі NEBI/RSV, 92,31\% - у групі RSV та $11,83 \%$ - у групі NEBI (NEBI/RSV проти RSV, $p=0,163 ; \mathrm{NEBI} / \mathrm{RSV}$ проти NEBI, $\mathrm{p}<0,001$ ) (рисунок, в).

Частота розвитку побічних ефектів становила $8,51 \%$ у групі NEBI/RSV, 7,45\% - у групі RSV та 8,60\% - у групі NEBI, але не виявлено суттєвої різниці між трьома групами.

\section{Обговорення}

Це перше контрольоване проспективне дослідження, результати якого продемонстрували, що комбінована терапія небівололом та розувастатином $\epsilon$ ефективною та безпечною стратегією лікування пацієнтів із АГ та гіперліпідемією. Зниження рівня АТ при комбінованій терапії небівололом та розувастатином не поступалося ефективності монотерапії небівололом, а зниження рівня ХС ЛПНЩ при комбінованій терапії небівололом та розувастатином не поступалося ефективності монотерапії розувастатином. Результати цього дослідження продемонстрували, що терапія комбінацією небівололу та розувастатину та монотерапія цими препаратами суттєво знижувала частоту серцевих скорочень, а в деяких учасників дослідження супроводжувалася розвитком симптоматичної брадикардії. Результати щодо безпеки продемонстрували, що загальний показник частоти розвитку побічних ефектів, асоційованих із терапією цими препаратами, не відрізнявся у групах.

Відомо, що тривале лікування статинами асоціюється з розвитком цукрового діабету [11]. I навпаки, терапія небівололом сприятливо впливає на резистентність до глюкози та інсуліну, що, відповідно, забезпечує протилежний ефект від терапії статинами і підтверджується результатами цього дослідження $[12,13]$. Так, у жодної 3 досліджуваних груп не відзначали підвищення рівня глюкози і глікозильованого гемоглобіну ( $\mathrm{HbA1C}$ ) натще. Однак необхідним $\epsilon$ проведення подальших великих когортних досліджень, які би більш детально оцінили ефективність та безпеку комбінованої терапії небівололом та розувастатином щодо показників рівня глюкози і $\mathrm{HbA} 1 \mathrm{C}$.

\section{Висновок}

Результати цього дослідження продемонстрували, що комбінація небівололу та розувастатину $\epsilon$ зіставною за ефективністю та безпекою з монотерапією цими препаратами щодо зниження рівня АТ та ХС лпНЩ у пацієнтів із АГ та гіперліпідемією. Таким чином, комбіновану терапію небівололом та розувастатином можна без побоювань призначати пацієнтам із АГ та гіперліпідемією з метою лікування та профілактики ССЗ.

\section{Список використаної літератури/References:}

1. Johnson M.L., Pietz K., Battleman D.S. et al. (2004) Prevalence of comorbid hypertension and dyslipidemia and associated cardiovascular disease. Am. J. Manag. Care, 10(12): 926-932.

2. Jackson R., Lawes C.M., Bennett D.A. et al. (2005) Treatment with drugs to lower blood pressure and blood cholesterol based on an individual's absolute cardiovascular risk. Lancet, 365: 434-441. doi:10.1016/50140-6736(05)70240-3.

3. Emberson J., Whincup P., Morris R. et al. (2004) Evaluating the impact of population and high-risk strategies for the primary prevention of cardiovascular disease. Eur. Heart J., 25(6): 484-491. doi: 10.1016/j.ehj.2003.11.012.

4. Mach F., Baigent C., Catapano A.L. et al. (2019) 2019 ESC/EAS Guidelines for the management of dyslipidaemias: lipid modification to reduce cardiovascular risk. Eur. Heart J., 41(1): 111-188. doi: 10.1093/eurheartj/ehz455.

5. Whelton P.K., Carey R.M., Aronow W.S. et al. (2018) 2017 ACC/AHA/AAPA/ABC/ACPM/AGS/ APhA/ASH/ASPC/NMA/PCNA guideline for the prevention, detection, evaluation, and management of high blood pressure in adults: a report of the american college of cardiology/ american heart association task force on clinical practice guidelines. Hypertension, 71: e13-e115.

6. NICE (2020) Hypertension in adults: diagnosis and management. NICE guideline [NG136], Mar. 13.

7. Marketou M., Gupta Y., Jain S. et al. (2017) Differential metabolic effects of beta-blockers: an updated systematic review of nebivolol. Curr. Hypertens. Rep., 19: 22. doi:10.1007/s11906017-0716-3.

8. Williams B., Mancia G., Spiering W. et al. (2018) ESC/ESH Guidelines for the management of arterial hypertension. Eur. Heart J., 39: 3021-3104.

9. Münzel Th., Gori T. (2009) Nebivolol: the somewhat-different beta-adrenergic receptor blocker. J. Am. Coll. Cardiol., 54: 1491-1499. doi:10.1016/j.jacc.2009.05.066

10. National Cholesterol Education Program (NCEP) Expert Panel on Detection, Evaluation, and Treatment of High Blood Cholesterol in Adults (Adult Treatment Panel III) (2002) Third Report of the National Cholesterol Education Program (NCEP) Expert Panel on Detection, Evaluation, and Treatment of High Blood Cholesterol in Adults (Adult Treatment Panel III) final report. Circulation, 106(25): 3143-421.

11. Sattar N., Preiss D., Murray H.M. et al. (2010) Statins and risk of incident diabetes: a collaborative meta-analysis of randomised statin trials. Lancet, 375: 735-742. doi:10.1016/501406736(09)61965-6.

12. Rizos E., Bairaktari E., Kostoula A. et al. (2003) The combination of nebivolol plus pravastatin is associated with a more beneficial metabolic profile compared to that of atenolol plus pravastatin in hypertensive patients with dyslipidemia: a pilot study. J. Cardiovasc. Pharmacol. Ther., 8: 127-134. doi:10.1177/107424840300800206.

13. Ozyildiz A.G., Eroglu S., Bal U. et al. (2017) Effects of carvedilol compared to nebivolol on insulin resistance and lipid profile in patients with essential hypertension. J. Cardiovasc. Pharmacol. Ther., 22: 65-70. doi:10.1177/1074248416644987. 